\title{
APRESENTAÇÃO | PRESENTATION
}

O seminário internacional "Brasilidades: Jewish belonging in Brazilian Literature" ("Brasilidades: pertencimento judaico na Literatura Brasileira") promovido em 5 e 6 de maio de 2014 pelo Dahlem Humanities Center da Freie Universität Berlim (Universidade Livre de Berlim) no Goethe-Institut São Paulo, organizado pela Profa. Dra. Susanne Zepp em cooperação com o Centro de Estudos Judaicos da USP e com o Instituto de Estudos da Linguagem da UNICAMP trouxe a São Paulo estudiosos da Alemanha, de Israel e de várias universidades brasileiras para abordar novas perspectivas das representações literárias da experiência judaica no Brasil.

Para além de autores conhecidos como Samuel Rawet, Moacyr Scliar e Clarice Lispector - referências obrigatórias neste tema - buscou-se, também, contemplar autores contemporâneos, ou desconhecidos do grande público.

Uma parte dos trabalhos apresentados no âmbito deste seminário internacional acabou por transformar-se em artigos acadêmicos, que a presente edição dos Cadernos de Língua e Literatura Hebraica agora publica. Aqui estão, por exemplo, um estudo pioneiro sobre a obra de Marcos Iolovich, um estudo sobre os cruzamentos entre a obra plástica e a obra poética de Leila Danziger, uma análise das colunas jornalísticas que Clarice Lispector publicou nos anos 1960 e 1970, um estudo sobre a recepção da obra poética de Paul Celan no cenário poético contemporâneo no Brasil, e outros trabalhos originais, que desvendam novas perspectivas do fecundo tema das relações entre tradição judaica e cultura brasileira.

É também neste contexto que publicamos uma crônica inédita da escritora Heloísa Pait, que aborda um tema sempre atual nos estudos judaicos brasileiros: o dos conflitos com as realidades da ditadura militar, nos anos 1970, cuja lembrança ainda paira, como uma grande sombra, sobre a realidade brasileira atual.

Para além do tema central, porém, esta edição contempla, também, outras áreas dos estudos judaicos, que são parte da pauta dos Cadernos de Língua e Literatura Hebraica desde a criação deste periódico, em 1998. Destacam-se, ai, os estudos bíblicos, representados nesta edição por um artigo que discute as representações da misteriosa figura bíblica de Melquisedec no Midrash Rabá, assim como a literatura hebraica, com um artigo de Nancy Rozenchan que trata das representações contemporâneas do genocídio na obra Shoá shelanu [Nossa Shoá], de Amir Gutfreund, e com um artigo de Gabriel Steinberg, que discute os ideais subjacentes ao romance Mozart não era judeu, de Gabriela Avigur Rotem. 
Esperamos que estes artigos possam abrir novos caminhos para a reflexão acadêmica.

Moacir Amâncio e Luis S. Krausz 